\title{
8 Education, sustainable development and resource management
}

\author{
Katrin Kohl and Charles A. Hopkins
}

\section{Introduction: today's approach to resource management in the economy}

The goal of almost every country is to grow its economy and provide better living conditions for its citizens. Many nations have mainly been successful in these attempts. While the global population continues to grow (UNDESA 2019), the combined gross domestic product GDP) is growing even faster, indicating that globally the available total of goods and services per capita is increasing at an astonishing rate (UNDESA/UNCTAD 2019).

The unprecedented development reflected in GDP continues to happen although humankind's growth has long exceeded the Earth's carrying capacity, i.e. the ability of the natural systems to support life without environmental degradation. It is estimated the carrying capacity was exceeded around 1976 (Wackernagel et al. 2002). The Earth's population at that time was a little over 4 billion and the total gross domestic product was USD 6.4 trillion (World Bank 2019a, 2019b). By 2018, the population reached 7.6 billion people. However, the accompanying gross domestic product expanded proportionally at a much faster rate, exceeding USD 80 trillion (World Bank 2019a, 2019b). Is this of concern?

Collectively, our lifestyles are greatly enhanced by the burgeoning services provided but at a considerable cost to the environment and draw-down to the natural resources. With humans becoming the dominating force in impacting the planet, it is accepted that through human impact on the planet we are entering the yet unprecedented era of the Anthropocene.

Today's economies, while experiencing this remarkable enhanced pace in their developments, are still highly dependent on the use of natural resources (European Commission 2011). Even with our new-found awareness of global transformations of fundamental life-sustaining natural processes, the removal of non-renewable resources, and the depositing of harmful man-made substances in crucial areas, there is little global discussion or accompanying action initiated to aim at a limit to this exponential economic growth. 


\section{The interdependence of accelerated economic growth and fading natural resources}

The unfettered growth dilemma has long been known. Reaching international attention in 1962 with her book Silent Spring, Rachel Carson drew the connection between economic growth and development with environmental degradation (Carson 1962). When the concept of limits to growth in the context of natural resources was first discussed in the late 1960s by Donella and Dennis Meadows (Meadows et al. 1972), the counter-argument was that scarcity of resources would lead to rising prices. Higher resulting market prices would drive the demand for alternatives to the current (natural) resource and new services, or products would emerge to solve any shortage. But this market theory only works for resources that are replaceable by substitutes.

To date, we are not able to create substitutes for many of the natural resources that are in heavy use or threat by today's economies. Problems abound with substituting breathable air, potable water, oil, natural gas, phosphorus, minerals, etc. If even possible to re-create, the substitute often comes at a higher price and with further - frequently negative - implications. Additionally, in creating the substitute yet another indirectly related resource impact is to be taken into account.

The next recognition of the problem of resource scarcity or depletion and the need for management came in the 1970s and early 1980s during an unprecedented emphasis on environmentalism, mainly in the developed world. While people in the developing world equally treasured their natural resources, they were faced with addressing abject poverty as they struggled with newfound nationhood, being recently emancipated from the status of the colony.

For the first time, in 1987, the United Nations adopted a compromise approach between environmentalism and development. It was the concept of sustainable development:

Sustainable development is development that meets the needs of the present, without compromising the ability of future generations to meet their own needs.

(Brundtland Report 1987)

According to Our Common Future, development is sustainable when it meets the needs of present human development without compromising natural systems and their ability to serve future generations in meeting their own needs (Brundtland Report 1987). Three interconnected areas are thought to be aspects of sustainable development: environment, society, and economy. These three aspects are to be addressed in balanced, interconnected and systemic approaches. The concept of sustainable development is not fighting capitalism or growth but targeting a positive impact from development that sustains the carrying capacity of the planet both now and in the future. The goal is to foster economies and well-being of all life while restoring and enhancing the planet's natural systems. 
Today's economies are still struggling with this paradigm of sustainable development. While aiming at national targets of ambitious economic development, countries are striving to simultaneously meet their international obligations to preserve existing natural resources. Traditionally, these two goals are seen as mutually exclusive initiatives. The current challenge is to prove this understanding to be fundamentally wrong. The international community aims at collaboratively creating a global economic system that enables countries to thrive, serve its citizens equitably and sustain the carrying capacity of the environment for future generations.

Two crucial questions arise:

1 How can the complexity of change be understood to move away from further economic development based on harmfully excavating the planet towards sustainable growth with efficient use of (natural) resources?

2 How can education systems support these initiatives to create a new path to sustainable resource consumption and management worldwide?

\section{The role of education in understanding the need for a sustainable development}

When the United Nations adopted the concept of sustainable development in 1987, they subsequently began to negotiate an implementation plan, later called Agenda 21 (UNCED 1992). Creating this agenda took five (5) years and was facilitated not only by the negotiating governments but with the private sector and civil society forming a global partnership for sustainable development. Each group interpreted sustainable development in its perspectives and objectives. For instance, the private sector understood sustainable development in terms of eco-efficiency and hence profitability while civil society saw the concept more in terms of environmental protection, social justice and equity. Finally, in 1992 at the United Nations Conference on Environment and Development in Rio de Janeiro (Brazil), Agenda 21 comprised of 40 chapters was adopted. One of the only chapters in Agenda 21 that passed quickly and with the full support of member states was Chapter 36 Promoting Education, Public Awareness and Training (UNCED 1992). The need for these three items as crucial means of implementing not only Agenda 21 but sustainability itself was largely self-evident to world leaders. Without an educated populace, there would be limited development of any kind let alone sustainable. However, simply more education as in the developed countries would not address sustainability. It was also decided that the purpose of education should be reoriented from development towards sustainable development. Following the 1992 Conference, also known as the 'Earth Summit', the concept of education, public awareness and training with the added focus of reorienting education systems as a unified initiative became known merely as Education for Sustainable Development (further: ESD) with its four thrusts. 
UNESCO was mandated as the UN agency responsible for the promotion and implementation of ESD on the international level. UNESCO had a history of developing conceptual approaches to education that looked at the outcomes in a humanistic and holistic way, recommending approaches to education beyond the preparation of a workforce to foster national economies.

By 1972, with the Faure Report (Faure et al. 1972), UNESCO had already recognised the need to adapt to the enhanced economic growth with the accompanying exhaustion of resources for power and food as a major future challenge. In 1996, a second major education report, the Delors Report was published (Delors 1996) that included preliminary concepts of ESD. The document recognised global interconnectedness and promoted learning in partnership while linking education to development policies.

The role of ESD was internationally strengthened with the adoption of the United Nations Decade of Education for Sustainable Development 2005-2014 (UNESCO 2005). At the Decade's concluding conference, UNESCO member states explicitly agreed upon the need to review the purposes and values underpinning education in their Aichi-Nagoya Declaration on Education for Sustainable Development (UNESCO 2014a).

The Global Action Programme on Education for Sustainable Development 2015-2019 (commonly referred to as GAP, UNESCO 2014b) created further momentum in advance of the adoption of the Transforming our World: the 2030 Agenda for Sustainable Development with the Sustainable Development Goals (SDGs) at its core (United Nations 2015).

Unlike the previous United Nations Millennium Development Goals (MDGs) (United Nations 2000), the 17 SDGs in a historic move now addressed all member states equally and called for fundamental changes to transform our world by 2030. If sustainable development is not achieved globally, climate change, environmental degradation and shifts in human mobility will appear to new extents (United Nations 2015).

SDG 4 on Quality Education defines the work program for all levels of formal education within the 2030 Agenda under the coordination of UNESCO. Abstract concepts, such as ESD and global citizenship, are now explicitly integrated with the seven targets of SDG 4. As education was understood as a means of success for the achievement of the SDGs, the Education 2030 Framework For Action was adopted before at the World Education Forum 2015 in Incheon (South Korea) (UNESCO 2015). Ministers of education and education experts also agreed to monitor their countries' progress on the seven targets in SDG 4 in an independent annual Global Education Monitoring Report (commonly referred to as GEMR, see also UNESCO 2016a).

Today, ESD is recognised 'as an integral element of the Sustainable Development Goal on quality education and a key enabler of all the other Sustainable Development Goals' (United Nations 2018), and explicitly stated in SDG target 4.7. This statement revealed the role of ESD well beyond SDG 4 focusing on education and recognised the roles of education, public awareness and training in achieving most other SDGs as well. It is evident that ESD would 
be a crucial means of implementing SDG 1 No Poverty, SDG 2 Zero Hunger and SDG 3 Good Health and Well-being. From a resource management perspective, the implementation of SDGs 6 Clean Water and Sanitation, 12 Responsible Consumption and Production, 14 Life below Water and 15 Life on Land would be enhanced by including aspects of ESD.

To further ESD as a crucial concept to be embedded in formal education and training systems, a new stand-alone UNESCO-coordinated work programme following the GAP will be launched in 2020 named the ESD for 2030 Framework (UNESCO 2019a) broadening the transformative power of ESD for the achievement of all the SDGs.

UNESCO also remains a central force in bringing forward contemporary philosophical concepts of education and its purposes. A new report is planned, titled Futures of Education, to follow the Faure Report and the Delors Report, with a focus on the impact of artificial intelligence and technology on humankind. The role of education in the future of sustainability is one of the focus areas in this new undertaking (UNESCO 2019b).

Infusing ESD with its three perspectives recognised at the Earth Summit in 1992, i.e. education, public awareness and training, into mainstream education and training systems at all levels requires new thinking. Societies need to rethink the purpose of their education systems in today's world for the generations that will shape a future, yet unknown and impossible to envision. This rethinking is not just a matter of enhanced quantity of education to create the needed changes as currently, the most educated countries are leaving many of the deepest ecological footprints on the planet.

Recognising the need for this reorientation from development to sustainable development will not come easily. Other than many of the developing countries, developed countries do not fully experience major consequences of their lifestyles. They are unlikely to see the injustice and recognise that due to developing countries' inadequate infrastructure and minimal overall resilience, they pay disproportionately for the escalating costs of changing weather phenomena, sea-level rise and forced relocation. Those in the distant developed world likely do not consider that the lifesaving measures, forced on developing nations, divert funds from core services such as healthcare, education and infrastructure. ESD can help address this need for profound human consumptive change to make the planet not only last longer but to create a restorative use of resources and making a sustainable future possible.

Most education systems, still rooted in the age of the industrial revolution, are slow in adapting to change in structures (UNESCO 2019b), and ESD remains a 'Forgotten Priority'. Issues, such as resource management, sustainable production and consumption, biodiversity depletion, climate change and other global issues are not currently seen as concerns of formal education systems and remain as optional topics at best. Despite calls to prepare teachers to address ESD, only $7 \%$ of countries include ESD in teacher education as a mandatory element (McEvoy 2017; UNESCO 2017). The infusion of ESD has not reached its full potential (UNESCO 2016a). 


\section{The opportunity for education systems to further sustainable development}

Some education systems have recognised the necessary turnaround and are underway educating future generations to assume their role as citizens of a sustainable planet with social, economic and environmental justice. However, getting ministries of education to raise the profile, alter curricula, provide professional development and embed ESD concepts in monitoring and evaluation criteria is still in the distant future in most countries.

Likewise, without public awareness and understanding of the concept of sustainability, lawmakers will not be able to implement the needed legislative and policy changes. Governments are usually concerned with remaining in power and find it challenging to bring in policies without public support, regardless of how necessary they may be. Building a knowledgeable public that will understand and support the profound change to currently accepted and preferred lifestyles, takes concerted planning, effort and resources. Especially, since the impact of the local change will largely benefit those on the other side of the planet, it is crucial to comprehend the world's interdependencies and one's individual impact.

Also, without education and training, the needed shifts in both production and consumption practices will not be forthcoming. This need to address consumptive practices is a complex issue requiring combined input from a wide range of academic disciplines, especially focussing on social sciences and humanities. In sustainable production, the range of disciplines involved is equally great and include but are not limited to natural and applied sciences. Emerging ecological concepts, such as biomimicry, bio-engineering and Nano-technology also have roles to play. While technology and artificial intelligence are holding major promises for the well-being of humankind, they also raise major concerns with their impact on all life forms that share our planet (UNESCO 2019b). Essential considerations, such as the issues of ease, cost and social acceptance add to the complexity.

Understanding the 17 SDGs as a possible forecaster of the economy of the future may help raise the profile of both sustainable development and ESD. If addressing the major sustainability issues, including the implications for natural resource management, both as aspects of a future overall global economy, as well as the current perception of sustainability as a moral or ethical issue may bring more public concern and eventual action. The perception of the 17 SDGs as harbingers of the next economy is not unfounded as these issues are already being addressed and will likely only rise in global and local priorities.

In educating the existing workforce for a sustainable future, there is a need to create specialised programming. Understanding new approaches to creating a sustainable economy differs from the normal up-skilling of an experienced professional or the retraining of workers from a disappearing profession to a new emerging green concept. This complexity is further heightened for the 
new workforce that is about to enter. Training and preparation for employment in larger (green) enterprises or multinational corporations (MNCs) require different sets of technical and interpersonal or soft skills than in small to medium-sized enterprises (SMEs). SMEs are highly dependent on education systems to deliver the workforce immediately needed and usually do not have their in-house training capability. They require the pre-existence of highly trained new employees. MNCs want employees with communications skills, the ability to learn and willingness to move from position to position within the corporation and create their sustainability training approaches. However, both SMEs and MNCs do need the training to be successful in shifting to a sustainable economy. A further layer is added when one considers the need to have workers who can become entrepreneurs as well, creating their own sustainably managed business. These challenges need immediate recognition and addressing by education systems in synergy with the public and private sectors.

Fortunately, there are policy frameworks, programs and innovative pilot projects within both government agencies and the private sector to create or address greening the economy (see also UNEVOC 2017). But again, a concerted synergistic approach by formal education in partnership with other stakeholders in creating a more sustainable future is still too sporadic.

As well as the role of education and training for sustainable production is the role of enterprises of all sizes in shaping the consumer of the future. While too many consumers in the world are limited by poverty or lack of available choice, there remains a large and growing segment of societies who can steer and influence consumption through their purchasing decisions. It is in this wealthier segment of society, where a choice is an option that education and training regarding the best use of the world's resources can be an effective tool.

Having an interest in and understanding of the total lifecycle of the product: its circumstances of origin, including ecological and social implications, transportation footprint, disposal or re-use capability, owned or leased, and overall value to the consumer, are all skills that currently are too often supplanted by consideration of price alone. Further understanding of future issues, such as the circular economy, total cost perspectives and the implications of tax evasion/avoidance are all issues that would be relevant in a meaningful approach to ESD within formal education.

In synergy with ESD, the overarching concept of well-being addresses global and local resource-oriented sustainability issues. An understanding of subjective well-being is needed as it relates to both the individual and includes all life forms with whom we share the planet (UNESCO 2016b). Well-being is more than 'well-off' or wealthy and addresses many aspects, including meaningfulness of one's life, as well as meeting our Maslowian needs. Embedded in sustainability are concepts of individual well-being, societal well-being and well-being for all living entities. Even respect for cultural objects and customs needs consideration. Developing a sense of responsibility for the well-being of future generations, a concept emblazoned in the culture 
of Indigenous societies, but now lost mainly within our more developed civilisations, needs to be revisited if we are to address sustainable resource management.

\section{Outlook}

We know much about developing a sense of respect for our natural resources. It begins with awareness, is enhanced by contact and the respect progresses with ongoing learning and engagement. There are many ways of meaningful involvement with our precious natural resources to create a sense of concern, ownership and responsibility. It is this engagement that is the beginning of a lifelong relationship and concern for our planet and the elements that comprise its delicate, interdependent existence.

The Earth is finite. We can find substitutes for some depletions, but inexperience in both anticipating and facing future resource issues abounds. Profound questions of access, use and disposal/re-use of resources are now before us. Who will discuss, recommend and decide the answers? Hopefully, it will be knowledgeable, unselfish and globally-minded citizens who also have an awareness of intergenerational responsibility that extends beyond humans. We will not have such a cadre of citizens without the structured involvement of our formal education systems. It is time to nourish this engagement.

\section{Abbreviations}

ESD education for sustainable development

SDGs Sustainable Development Goals

UNCED United Nations Conference on Environment and Development

UNCTAD United Nations Conference on Trade and Development

UN DESA United Nations Department of Economic and Social Affairs

UNESCO United Nations Educational, Scientific and Cultural Organization

\section{References}

Brundtland Report (1987). Report of the World Commission on Environment and Development. Our Common Future. Retrieved 26 July 2019 from https://sustainabledevelopment.un. org/content/documents/5987our-common-future.pdf.

Carson, R. (1962). Silent Spring. Boston, MA: Houghton Mifflin Harcourt.

Delors, J. (1996). Learning: The Treasure Within-Report to UNESCO of the International Commission on Education for the Twenty-first Century. Paris: UNESCO. Retrieved 26 July 2019 from http://unesdoc.unesco.org/images/0010/001095/109590eo.pdf.

European Commission (2011). Roadmap to a Resource Efficient Europe. Communication from the Commission to the European Parliament, the Council, the European Economic and Social Committee and the Committee of the Regions. Brussels: European Commission.

Faure, E., Herrera, F., Kaddoura, A., Lopes, H., Petrovsky, A. V., Rahnema, M., and Ward, F. C. Learning to Be. (1972). The World of Education Today and Tomorrow. Paris: UNESCO. Retrieved 26 July 2019 from www.unesco.org/education/pdf/15_60.pdf. 
McEvoy, C. (2017). Historical Efforts to Implement the UNESCO 1974 Recommendation on Education in Light of 3 SDGs Targets. Retrieved 26 July 2019 from https://unesdoc. unesco.org/ark:/48223/pf0000247275.

Meadows, D. H., Meadows, D. L., Randers, J., and Behrens III, W. (1972). The Limits to Growth: A Report for the Club of Rome's Project on the Predicament of Mankind. New York: Universe Books.

UNCED (1992). Earth Summit, Agenda 21, Chapter 36: Promoting Education, Public Awareness and Training. Retrieved 2019, July 26, from www.un-documents.net/ agenda21.htm.

UNDESA (2019). United Nations Department of Economic and Social Affairs: World Population Prospects 2019. Retrieved 26 July 2019 from https://population.un.org/ wpp/Download/Standard/Population/.

UNDESA/UNCTD (2019). World Economic Situation and Prospects 2019. New York: United Nations publication.

UNESCO (2005). United Nations Decade of Education for Sustainable Development (2005-2014): International Implementation Scheme. Paris: UNESCO Education Sector. Retrieved 26 July 2019 from http://unesdoc.unesco.org/images/0014/001486/148654e.pdf.

UNESCO (2014a). Aichi-Nagoya Declaration on Education for Sustainable Development. Retrieved 26 July 2019 from http://unesdoc.unesco.org/images/0023/002310/231074e.pdf.

UNESCO (2014b). Roadmap for Implementing the Global Action Programme on Education for Sustainable Development. Paris: UNESCO. Retrieved 26 July 2019 from http://unesdoc. unesco.org/images/0023/002305/230514e.pdf.

UNESCO (2015). Education 2030: Incheon Declaration and Framework for Action for the Implementation of Sustainable Development Goal 4. Retrieved 26 July 2019 from https://unesdoc.unesco.org/ark:/48223/pf0000245656.

UNESCO (2016a). Global Education Monitoring Report 2016: Education for People and Planet: Creating Sustainable Futures for All. Paris: UNESCO. Retrieved 26 July 2019 from http://unesdoc.unesco.org/images/0024/002457/245752e.pdf.

UNESCO (2016b). UNESCO Strategy on Education for Health and Well-being: Contributing to the Sustainable Development Goals. Paris: UNESCO. Retrieved 26 July 2019 from https://unesdoc.unesco.org/ark:/48223/pf0000246453.

UNESCO (2017). Global Education Monitoring Report 2017/18: Accountability in Education: Meeting Our Commitments. Paris: UNESCO. Retrieved 26 July 2019 from https://unesdoc.unesco.org/ark:/48223/pf0000259338.

UNESCO (2019a). Education for Sustainable Development: Towards Achieving the SDGs (ESD for 2030). Paris: UNESCO. Retrieved 26 July 2019 from https://unesdoc.unesco.org/ ark:/48223/pf0000366797 (draft framework).

UNESCO (2019b). The Future of Education Report. Paris: UNESCO. Retrieved 26 July 2019 from https://unesdoc.unesco.org/ark:/48223/pf0000366976.

UNEVOC (2017). Greening Technical and Vocational Education and Training. A Practical Guide for Institutions. Bonn: UNESCO-UNEVOC. Retrieved 26 July 2019 from https://unevoc.unesco.org/up/Greening\%20technical\%20and\%20vocational\%20education $\% 20$ and $\% 20$ training_online.pdf.

United Nations (2000). United Nations Millennium Development Goals. Retrieved 26 July 2019 from www.un.org/millenniumgoals.

United Nations (2015). Transforming Our World: The 2030 Agenda for Sustainable Development. Retrieved 26 July 2019 from www.un.org/ga/search/view_doc.asp? symbol=A/RES/70/1\&Lang $=$ E. 
United Nations (2018). Decision 72/222. Education for Sustainable Development in the Framework of the 2030 Agenda for Sustainable Development. Retrieved 26 July 2019 from https://undocs.org/en/A/RES/72/222.

Wackernagel, M., Schulz, N. B., Deumling, N., Linares. A., Jenkins, M., Kapos, V., Monfreda, C., Loh, J., Myers, N., Norgaard, R., and Randers, J. (2002). Tracking the Ecological Overshoot of the Human Economy. Proceedings of the National Academy of Sciences of the United States of America. Volume 99. No. 14, pp. 9266.

World Bank (2019a). Population, Total. World Bank Databank. Retrieved 26 July 2019 from https://data.worldbank.org/indicator/SP.POP.TOTL?locations=1W.

World Bank (2019b). GDP (current US\$.). World Bank Databank. Retrieved 26 July 2019 from https://data.worldbank.org/indicator/NY.GDP.MKTP.CD?locations=1W. 